\title{
Some biological aspects of Leucothyreus femoratus (Burmeister) (Coleoptera, Scarabaeidae), in oil palm plantations from Colombia
}

\author{
L.C. Martínez, ${ }^{1}$ A. Plata-Rueda ${ }^{2}$ \\ ${ }^{1}$ Departamento de Entomologia, Universidade Federal de Viçosa; ${ }^{2}$ Departamento de Fitotecnia, \\ Universidade Federal de Viçosa, Minas Gerais, Brasil
}

\begin{abstract}
The scarabaeid Leucothyreus femoratus (Burmeister) is described as causing damage to oil palm leaves, marking its first report as a pest in Colombia. The presence of this insect has necessitated determination of its life cycle, biometrics and food consumption as important aspects of its biology. Experiments were conducted under laboratory conditions in the municipality of San Vicente, Santander, Colombia. Mass rearing of $L$. femoratus was conducted, simulating field conditions and eating habits under laboratory conditions. Its life cycle and description of its developmental stages were determined, taking into account stage-specific survival. The duration of the life cycle of $L$. femoratus was determined to be $170.4 \pm 6.53$, with an overall survival rate of $96.7 \%$. Biometrical measurements were taken of the insect's width, length and weight. Adults are black, and males and females are differentiated by size and by colour of their legs. The width, length and
\end{abstract}

Correspondence: Luis Carlos Martínez, Departamento de Entomologia, Universidade Federal de Viçosa, Avenida Peter Henry Rolfs, Campus Universitário Viçosa, Minas Gerais, Brasil; CEP: 36570-000.

Tel.: +55.31.3899.4012 - Fax: +55.31 .3899 .2108 .

E-mail: luis.castrillon@ufv.br ; plagas.martinez@gmail.com

Key words: biometry, consumption rate, insect pest, Leucothyreus femoratus, life cycle, rhizophagous.

Acknowledgements: the authors would like to thank Hugo Calvache and Alexander Villanueva for his contributions in this research. To the Universidad de La Paz (Colombia), Yarima Oil Plantation (Colombia), Conselho Nacional de Desenvolvimento Científico e Tecnológico CNPq (Brasil), Coordenação de Aperfeiçoamento de Pessoal de Nível Superior CAPES (Brasil) and Fundação de Amparo a Pesquisa do Estado de Minas Gerais FAPEMIG (Brasil).

Received for publication: 13 November 2012.

Revision received: 12 February 2013.

Accepted for publication: 18 February 2013.

(C) Copyright L.C. Martínez and A. Plata-Rueda, 2013

Licensee PAGEPress, Italy

Journal of Entomological and Acarological Research 2013; 45:e7

doi:10.4081/jear.2013.e7

This article is distributed under the terms of the Creative Commons Attribution Noncommercial License (by-nc 3.0) which permits any noncommercial use, distribution, and reproduction in any medium, provided the original author(s) and source are credited. weight of the insect are proportional to the growth stage. Daily food consumption rate was evaluated in adult $L$. femoratus, and damage to leaves of Elaeis guineensis is described. Adult $L$. femoratus consumed $13 \mathrm{~mm}^{2}$ of foliage per day, and injury to leaves of $E$. guineensis was square or rectangular in shape. This insect's life cycle duration and size are factors that could be considered in determining its feeding habits and pest status. Details of the life cycle, physical description and consumption rate of $L$. femoratus can help in the development of strategies to manage its populations in oil palm plantations.

\section{Introduction}

Extensive monocultures of oil palm (Elaeis guineensis Jacquin; Arecales, Arecaceae) promote the growth and development of defoliating insects that may impair the productivity of commercial plantations in the Americas. Different biotic and abiotic changes were induced by the introduction and establishment of $E$. guineensis in neotropical ecosystems, where it expands continuously as a crop, favoring colonization by phytophagous species endemic to the agroecosystem (Mariau $e t$ al., 1991; Martínez et al., 2009). Oil palm defoliators are represented by different insect species that exhibit variations in the nature of their damage, their population dynamics, and whether several species may be permanently present to simultaneously damage the plant (Genty et al., 1978; Chung et al., 1995).

Defoliation by insects reduces palm oil production by $5-30$ ton/ha/year (Wood et al., 1974). Defoliation of the top level of the canopy is very detrimental, and the plant may need up to two years to rebuild the canopy after being damaged (Corley, 1983; Henson, 1990). Foliar damage in palm can have a significant physiological impact, characterized by partial or total removal of the leaf, meristematic tissue destruction, vascular necrosis, reduced plant size, and biomass loss (Henson, 1991; Dufrene \& Saugier, 1993; Corley \& Donough, 1995). Although lepidopteran larvae from different families are the major insect defoliators in oil palm crops (Mariau et al., 1991; Martinez et al., 2009), some scarabaeid larvae are also problematic pests.

Scarabaeidae (Coleoptera) larvae live in the soil, feeding on decaying organic matter, whereas adults of some species feed on plant tissues and in some cases become an economic pest (Rodriguez-Del-Bosque, 1998; Pardo-Locarno et al., 2006). Rutelinae beetles in some countries in the Americas feed on roots of pastures and crops; (Rodrigues et al., 2008; Mico et al., 2003; Ramirez-Salinas et al., 2004). Species such as Melolontha melolontha (F.), Omaloplia spireae (Pallas) and Popillia japonica (Newman) damage leaves of a variety of plants in Asia and Europe (Fulcher et al., 1998; Egert et al., 2005; Kulkarni et al., 2007). Studies on the biology of oil palm pests such as (Oryctes rhinoceros (L.) and Strategus aloeus (L.) have been used as a starting point for the adoption of control methods and strategies (Bedford, 1976; Ahumada et al., 1995). 
The occurrence of Leucothyreus femoratus (Burmeister) (Coleoptera, Scarabaeidae) in oil palm crops marks the first report of this species as pest in Colombia. The objective of this study was to determine the life cycle, biometric details and food consumption rate of $L$. femoratus in oil palm, and to provide external morphological descriptions of its developmental stages.

\section{Materials and methods}

\section{Insects}

Field specimens of $L$. femoratus adults $(\mathrm{n}=533 ; \hat{\jmath}=251, \quad+=282)$ were captured at night by hand in 2-year-old commercial plantations of oil palm in the municipality of San Vicente, Santander, Colombia (N $06^{\circ} 54$ ', W $73^{\circ} 28^{\prime}$ ), which has an average temperature of $27.32^{\circ} \mathrm{C}$, $75-81 \%$ relative humidity, $135-220 \mathrm{~h} /$ year of sunshine and $1879 \mathrm{~mm}$ annual rainfall. The captured adults were transferred into polystyrene boxes $(40 \times 40 \times 60 \mathrm{~cm})$ in the Plant Protection laboratory of Yarima 0il Plantation (San Vicente, Santander, Colombia) under conditions of controlled temperature $\left(26 \pm 2^{\circ} \mathrm{C}\right)$, humidity $(75 \pm 5 \%)$ and light $(12: 12 \mathrm{~h}$ L:D), where it was mass reared. The photophase and scotophase were simulated using fluorescent light and red light (IR0 110V 60W; Toshiba Lightning and Technology Corp., Tokyo, Japan). Only healthy adults without missing legs or malformations were used in bioassays.

\section{Life cycle}

Males and females of $L$. femoratus were isolated in glass vials $(10 \times 50$ $\mathrm{cm}$ ) containing $5 \mathrm{~cm}$ of soil, and were fed $E$. guineensis leaves. Eggs oviposited in the soil were collected every $24 \mathrm{~h}$ and were placed in Petri dishes $(90 \times 15 \mathrm{~mm})$ lined with damp filter paper. Emerged first-instar larvae were placed individually in plastic boxes $(10 \times 15 \mathrm{~cm})$ with a perforated lid and containing a 5 -cm layer of sterilized soil, and were fed Zea mays (L.) roots every 24 h. Z. mays roots were cut from hydroponically grown plants, and placed in the boxes at a rate of $5 \mathrm{~g}$ of root/larva. Adults were placed in glass containers $(30 \times 30 \times 30 \mathrm{~cm})$ that were covered with nylon mesh and fed $E$. guineensis leaves. Data on the insect's life cycle, range of longevity, and survival (\%) were recorded at intervals of 6,12 and $24 \mathrm{~h}$.

\section{Biometry and description}

Developmental stages of the insects were described using the main aspects of its external morphology. Measurements were conducted on
210 individuals, to determine length and width using an electronic caliper, and weight using an analytical balance. Additionally, images of each developmental stage of $L$. femoratus were taken using a digital camera (D40, 18-55 mm, Nikon Corp., Tokyo, Japan).

\section{Consumption rates and damage}

Males and females of $L$. femoratus were isolated in glass vials $(10 \times 15$ $\mathrm{cm}$ ) containing $5 \mathrm{~cm}$ of soil in the bottom, and fed on young leaflets of E. guineensis wrapped in a cotton cloth to prevent weight loss due to dehydration. Foliar consumption $\left(\mathrm{mm}^{2}\right)$ by individuals of both sexes $(n=200 ; \hat{\delta}=100, q=100)$ from adult emergence to 60 days post-emergence was measured daily. The foliar area consumed was measured using an acetate sheet $\left(25 \times 35 \mathrm{~cm}\right.$, with $1 \mathrm{~mm}^{2}$ grids). Additionally, leaf injury caused by the insect was photographed and described.

\section{Data analysis}

Life cycle and biometry data of $L$. femoratus were analyzed using a one-way analysis of variance (ANOVA) and honestly significant difference (HSD) test at a significance level of $\mathrm{P}=0.05$ (Tukey, 1949). A paired t-test was used by comparing means of the daily consumption by males and females. All statistical parameters were analyzed with GLMMIX procedure using SAS v.9.0 for Windows (SAS, 2002).

\section{Results}

\section{Life cycle}

Individuals were obtained representing the different developmental stages of $L$. femoratus: egg $(\mathrm{n}=359)$, first instar larva $(\mathrm{n}=355)$, second instar larva $(\mathrm{n}=319)$, third instar larva $(\mathrm{n}=294)$, pupa $(\mathrm{n}=276)$ and adult $(\hat{\delta}=128, q=124)$. The mean duration of $L$. femoratus life cycle of was $170.4 \pm 6.53(\mathrm{~F}=39.32, \mathrm{P}<0.05)$, and the individual stages and larval instars were characterized by distinct duration times and an overall survival rate of $96.7 \%$ (Table 1).

\section{Biometry and description}

There are significant differences in the dimensions and weights of the different developmental stages of $L$. femoratus $(\mathrm{F}=9.21, \mathrm{P}<0.05$; Table 2). The egg (Figure 1A) is white and oval (1.5'1.7 mm at oviposition), and expands to three times its initial size before hatching, due to growth and development of the neonate within. Near to hatch, it is possible to observe the cephalic capsule of the neonate through the

Table 1. Duration of the developmental stages of Leucothyreus femoratus (Coleoptera: Scarabaeidae) under laboratory conditions $\left(26 \pm 2^{\circ} \mathrm{C}, 75 \pm 5 \%\right.$ relative humidity and $12 \mathrm{~h}$ scotophase).

\begin{tabular}{lcccc} 
Stage & Duration (days) & N & Range & Survival (\%) \\
Egg & $8.73 \pm 0.11$ & 360 & $7-10$ & 99.9 \\
$1^{0}$ instar & $12.26 \pm 0.48$ & 330 & $11-13$ & 98.7 \\
\hline $2^{\circ}$ instar & $24.21 \pm 1.05$ & 300 & $21-26$ & 96.9 \\
$3^{\circ}$ instar & $67.35 \pm 2.28$ & 270 & $63-72$ & 98.1 \\
\hline Larvae & $103.7 \pm 3.44$ & 330 & $63-72$ & - \\
Pupae & $9.27 \pm 0.80$ & 270 & $8-10$ & 92.1 \\
\hline Adult ${ }^{\lambda}$ & $46.35^{\mathrm{b}} \pm 4.81$ & 120 & $45-57$ & 98.6 \\
Adult +9 & $51.04^{\mathrm{a}} \pm 2.11$ & 120 & $48-60$ & 95.8 \\
\hline Adults & $48.69 \pm 2.18$ & 240 & $45-60$ & - \\
Egg-adult & $170.4 \pm 6.53$ & 360 & $151-192$ & 96.7 \\
\hline
\end{tabular}

$\mathrm{N}$, individuals tested. ${ }^{\mathrm{a}, \mathrm{b}}$ Values for adult males and females are significantly different $(\mathrm{P}<0.05$, Tukey's test). 


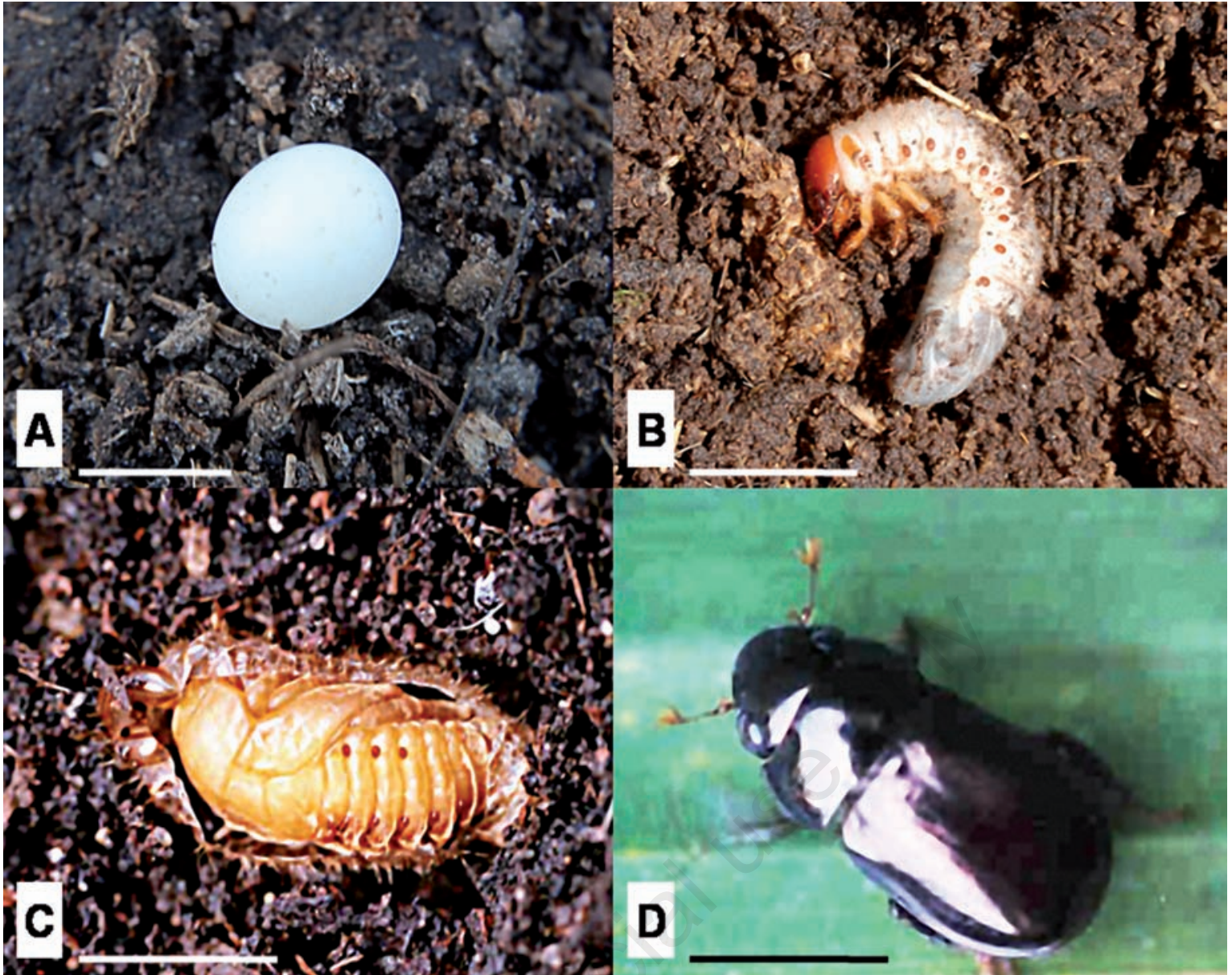

Figure 1. Stages of Leucothyreus femoratus (Coleoptera: Scarabaeidae) habitus. Egg (A) (bar=1 mm); larva (B); pupa (C); adult (D) (bar=5 mm).

Table 2. Mean $( \pm \mathrm{SD})$ width, length and weight of the developmental stages of Leucothyreus femoratus (Coleoptera: Scarabaeidae) under laboratory conditions $\left(26 \pm 2^{\circ} \mathrm{C}, 75 \pm 5 \%\right.$ relative humidity and $12 \mathrm{~h}$ scotophase).

\begin{tabular}{|c|c|c|c|c|c|c|}
\hline \multirow[t]{2}{*}{ Stages } & \multicolumn{2}{|c|}{ Width (mm) } & \multicolumn{2}{|c|}{ Length (mm) } & \multicolumn{2}{|c|}{ Weight (mg) } \\
\hline & Mean \pm SE & Range & Mean \pm SE & Range & Mean \pm SE & Range \\
\hline Egg & $1.5 \pm 0.03$ & $1.4-1.9$ & $1.7 \pm 0.02$ & $1.5-1.9$ & $1.91 \pm 0.04$ & $1.3-2.7$ \\
\hline $\begin{array}{l}\text { Larva } \\
1^{\circ} \text { instar } \\
2^{\circ} \text { instar } \\
3^{0} \text { instar }\end{array}$ & $\begin{array}{l}2.3 \pm 0.18 \\
3.6 \pm 0.12 \\
6.8 \pm 0.11\end{array}$ & $\begin{array}{l}1.5-3.1 \\
2.8-4.5 \\
5.4-12.0\end{array}$ & $\begin{array}{c}5.6 \pm 0.03 \\
11.9 \pm 0.1 \\
20.3 \pm 0.1\end{array}$ & $\begin{array}{c}4.3-6.9 \\
1.6-2.9 \\
17.1-24.9\end{array}$ & $\begin{array}{l}2.13 \pm 0.23 \\
14.5 \pm 3.16 \\
74.4 \pm 14.02\end{array}$ & $\begin{array}{c}1.7-3.7 \\
13.4-26.1 \\
56.3-123.8\end{array}$ \\
\hline $\begin{array}{l}\text { Pupa } \\
\text { Male } \\
\text { Female }\end{array}$ & $\begin{array}{l}6.4^{\mathrm{b}} \pm 0.13 \\
7.1^{\mathrm{a}} \pm 0.08\end{array}$ & $\begin{array}{l}10.9-13.6 \\
12.4-14.3\end{array}$ & $\begin{array}{c}9.4^{\mathrm{b}} \pm 0.09 \\
12.1^{\mathrm{a}} \pm 0.1\end{array}$ & $\begin{array}{l}5.0-5.9 \\
5.6-6.8\end{array}$ & $\begin{array}{r}74.1^{\mathrm{b}} \pm 8.63 \\
100.6^{\mathrm{a}} \pm 7.18\end{array}$ & $\begin{array}{l}67.5-99.2 \\
73.5-124.4\end{array}$ \\
\hline $\begin{array}{l}\text { Adult } \\
\text { Male } \\
\text { Female }\end{array}$ & $\begin{array}{l}4.5^{\mathrm{b}} \pm 0.1 \\
5.7^{\mathrm{a}} \pm 0.1\end{array}$ & $\begin{array}{l}3.9-6.5 \\
5.5-6.8\end{array}$ & $\begin{array}{c}8.3^{\mathrm{b}} \pm 0.10 \\
10.6^{\mathrm{a}} \pm 0.1\end{array}$ & $\begin{array}{l}7.9-9.12 \\
9.3-11.2\end{array}$ & $\begin{array}{l}20.2^{\mathrm{b}} \pm 1.28 \\
22.9^{\mathrm{a}} \pm 1.45\end{array}$ & $\begin{array}{l}17.2-31.1 \\
18.2-35.9\end{array}$ \\
\hline
\end{tabular}

SE, standard error. a,b Values between males and females of the same stage followed by a different letter are significantly different ( $\mathrm{P}<0.05$, Tukey's test). 
transparent membrane of the egg. Eggs are laid singly, then covered with substrate material by the female using her hind legs. The scarabeiform larva (Figure 1B) has a white body with short setae, and a brown pigmented head with visible epicranial and frontal sutures. There are five medium setae around the antennae. The ocelli group is visible at the base of the antennae. The clypeus and labrum are trapezoidal; the maxilla has asymmetrical lacinia with two unci, and a stridulatory area possessing ten teeth and short palidia. First instar larvae consume the exuvia as an initial food source after hatching. The hardening and sclerotization of the head requires 4-6 h, during which time the larva remains motionless. Dimensions of the larvae were variable depending on the instar (first instar, $2.3 \times 5.6 \mathrm{~mm}$; second instar, $3.6 \times 11.9 \mathrm{~mm}$, third instar, $6.8 \times 20.3 \mathrm{~mm}$ ). Larvae were seen situated around the roots of $Z$. mays and showed little mobility; cannibalism occurred during the third instar. The pupa (Figure 1C) is exarate, elongated and oval, and yellow in colour but turning brown at the end of the stage, with a bowed head and mouthparts directed backwards; eyes, antennae, mandibles and palps are clearly distinguishable. The thorax has distinct structures, and the abdomen is mobile with nine segments. Dimensions of the pupa are smaller, compared with the third instar larva $(\hat{\delta}=6.4 \times 9.4 \mathrm{~mm}, q=7.1 \times 12.1 \mathrm{~mm}),(\mathrm{F}=41.27, \mathrm{P}<0.05$; Table 2). Pupae are found in nesting chambers made during the last larval stage. The nesting chambers, constructed by the third instar larvae, are built with soil substrate mixed with saliva. The adult (Figure 1D) is black with large eyes; the clypeus is circular with a bent apex. The mandibles are exposed and lobed. The epipleura elytra does not possess points; protarsomeres are long, ventrally flattened, and possess setae. Males have yellow legs, a concave abdomen and the last sternite emarginated; females have black legs, a convex abdomen, and the last sternite with margin entire. Adult dimensions are smaller than those of the

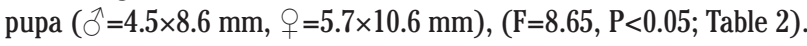

\section{Consumption rate and damage}

The average leaf area consumed by females, $12.4 \mathrm{~mm}^{2} / \mathrm{d}$, was significantly higher than by males, $8.2 \mathrm{~mm}^{2} / \mathrm{d}$ (paired t-test, $\mathrm{N}=200$, $\mathrm{t}=-0.0021, \mathrm{P}=0.998$ ). Damage caused by $L$. femoratus showed variations in the number, size and shape of leaves damaged. The main lesion feature was a rectangular or square-shaped area of damage extending from the leaf border to the central vein (Figure 2A). Damage was greater at the apex than at the base of the leaf (Figure 2B). More serious injuries occurred on leaves in close contact with other leaves. Also evident were damaged vascular duct channels and dried out areas around the lesions.

\section{Discussion and conclusions}

The life cycle of $L$. femoratus presented variations in the length of its developmental stages; in this insect, the longevity of the larvae was longer while the embryonic period was shorter. Duration of the total $L$. femoratus life cycle was $170.4 \pm 6.53$, including egg, $8.73 \pm 0.11$; larva, 103.7 \pm 3.44 ; pupa, $9.27 \pm 0.80$; and adult, $48.69 \pm 2.18(\mathrm{~F}=39.32, \mathrm{P}<0.05)$. Populations of $L$. femoratus could be found in all developmental stages under natural conditions. Differences in duration of developmental stages could explain the multivoltinism of this species. Studies on the life cycle and ecology of Leucothyreus dorsalis (Blanchard) showed that their populations can be univoltine or multivoltine (Rodriguez-DelBosque, 1998; Rodrigues et al., 2010). The egg-to-adult survival of $L$. femoratus under laboratory conditions was high, with a value of $96.7 \%$. The life cycles of other insect pests in oil palm, such as Oryctes rhinoceros (L.), Strategus aloeus (L.), and Scapanes australis (Boisduval) (Coleoptera, Scarabaeidae), were successfully determined under laboratory conditions (Bedford, 1976; Ahumada et al., 1995). Mortality of $L$. femoratus was higher in the pupal stage. One possible reason might be cannibalism observed during the study, especially in third instar larvae that consume smaller individuals and pupae. Similar antagonistic behavior involving severe attacks on the abdomen and locomotor appendages was observed in Oryctes agamemnon (Burmeister) (Soltani et al., 2008). It is unknown whether this insect shows similar behavior under natural conditions. The duration of the adult stage was higher in females than in males, with a difference of 3-12 days.

The size and weight of $L$. femoratus were variable among individuals and were proportional to growth of the eggs and larvae. Eggs increased in dimension until the time of hatching. The pupa and adult stages differed in size and weight by sex, the females having higher measure-

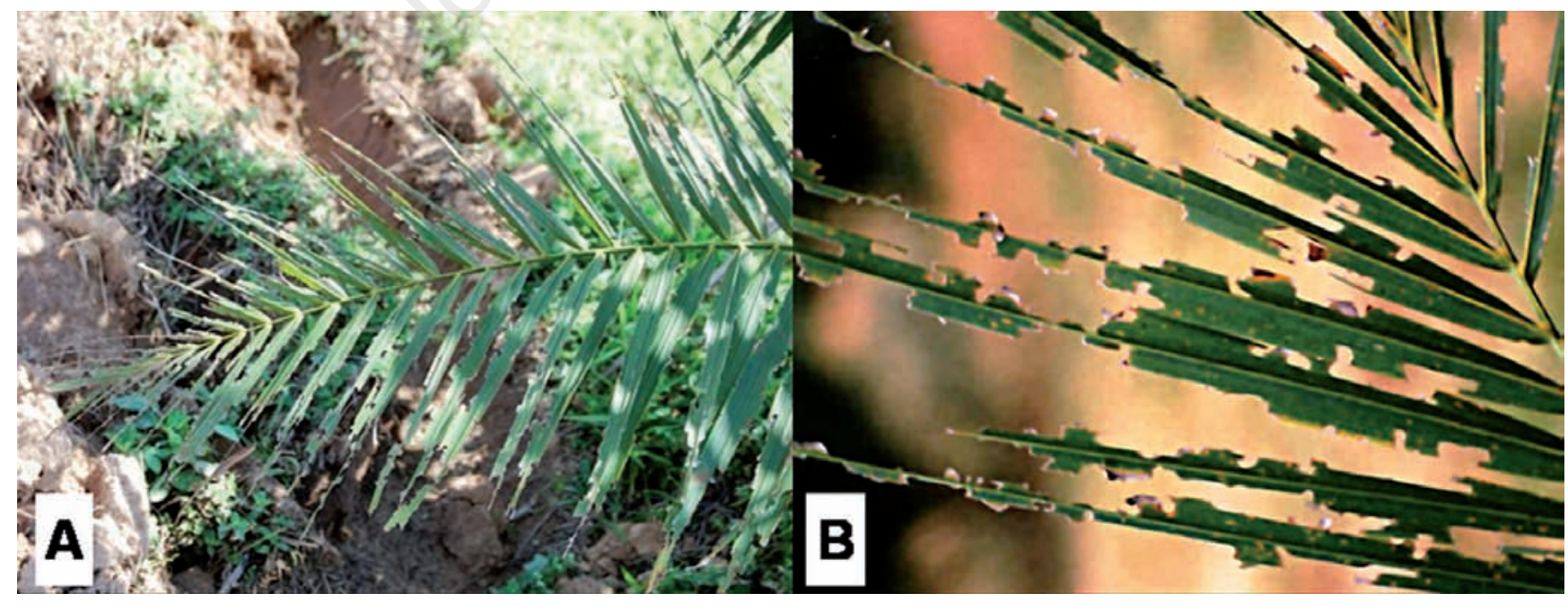

Figure 2. Injury caused by Leucothyreus femoratus to Elaeis guineensis in Colombia. Characteristic damage (A); initial defoliation in 2-year-old oil palm plantation (B). 
ments in both cases. Studies performed on the biometry of $L$. dorsalis, Anomala inconstans (Burmeister) and Anomala denticollis (Bates) (Coleoptera, Scarabaeidae) noted variations during the growth and development of each insect (Ramirez-Salinas and Castro-Ramírez, 2000; Rodrigues et al., 2010). It is possible that differences in the dimensions of $L$. femoratus may be explained by the conditions of reproduction and quality of food used under constant conditions of temperature, humidity and light $\left(26 \pm 2^{\circ} \mathrm{C}, 75 \pm 5 \%\right.$ and $\left.12 \mathrm{~h} \mathrm{L:D}\right)$. Different studies showed that beetles under controlled laboratory conditions can vary in their body size among individuals (Ritcher, 1958; Bedford, 1980). Sexual dimorphism of $L$. femoratus was verified by differences in size and in colour of the legs between males and females. The colouring process was observed during sclerotization, corresponding with the developmental changes observed in the insect.

The variation in the daily foliar consumption for males and females of $L$. femoratus may be related to the differences in size between the two sexes (Martinez et al., 2009). The square or rectangular shape of the foliar damage was similar to that reported for this insect in other palms such as Cocos nucifera (L.), Elaeis oleifera (Kunth) Cortés, and Bactris gasipaes (Kunth) (Martinez et al., 2009). The feeding preference of $L$. femoratus adults suggests that this insect may be classified as monophagous, as foliar phytochemical characteristics are common among species of Arecaceae (Bjorholm et al., 2005; Asmussen et al., 2006). In Malaysia, the insects Apogonia expeditionis (Ritsema), Apogonia cribicollis (Burmeister), Adoretus borneensis (Kraatz) and Adoretus compressus (Weber) (Coleoptera, Scarabaeidae) have been reported as defoliators in oil palm plantations, and other native plants (Hartley, 2002; Nordin et al., 2004). L. femoratus causes continuous damage to young plants. It is possible that the phenology of young palms and metabolic activity prior to the reproductive stage contribute to the high level of damage. The progressive loss of functional leaves affects photosynthesis, leading to reduced growth in young leaves, stems and roots (Henson, 1990; Darus \& Basri, 2001). Damage to the canopy in young palms may affect economic viability in commercial plantations, with delays in flowering, fruiting and production of 1-2 year (Wood et al., 1974; Corley, 1983; Giblin-Davis \& Howard, 1989).

The results of this research have contributed details of the life cycle and biometry of $L$. femoratus, and indicate that the food habits of the larva and adult may allow greater adaptability in commercial plantations of $E$. guineensis. The life cycle and size of this insect could be considered as factors in determining its potential damage in oil palm and status as a pest. This work may help to better understand the biology of this insect; altogether, these results contribute to the strategic use of effective tactics to control and manage $L$. femoratus populations.

\section{References}

AHUMADA M.L., CALVACHE H., CRUZ M., LUQUE J.E., 1995 - Strategus aloeus (L.) (Coleoptera: Scarabaeidae), biology and habits in Puerto Wilches (Santander). - Palmas 16: 9-16.

ASMUSSEN C.B., DRANSFIELD J., DEICKMANN V., BARFOD A.S., PINTAUD J.C., BAKER W.J., 2006 - A new subfamily classification of the palm family (Arecaceae): evidence from plastid DNA phylogeny. Bot. J. Linnean Soc. 151: 15-38.

BEDFORD G.0., 1976 - Observations on the biology and ecology of Oryctes rhinoceros and Scapanes australis (Coleoptera: Scarabaeidae: Dynastinae): pests of coconut palms in Melanesia. - J. Aust. Entomol. Soc. 15: 241-251.

BEDFORD G.0., 1980 - Biology, ecology and control of palm rhinoceros beetles. - Annu. Rev. Entomol. 25: 309-339.

BJORHOLM S., SVENNING J.C., SKOV F., BALSLEV H., 2005 -
Environmental and spatial controls of palm (Arecaceae) species richness across the Americas. - Global Ecol. Biogeogr. 14: 423-429.

CHUNG G.F., SIM S.C., HON K.M., RAMLI K., 1995 - Monitoring and surveillance system for integrated pest management of leaf eating caterpillars in oil palm. - Planter 71: 253-263.

CORLEY R.H.V., 1983 - Photosynthesis and age of oil palm leaves. Photosynthetica 17: 97-100.

CORLEY R.H.V., DONOUGH C.R., 1995 - Effects of defoliation on sex differentiation in oil palm clones. - Exp. Agr. 31: 177-189.

DARUS A., BASRI M., 2001 - Intensive MIP for management of oil palms pests. - Palmas 22: 19-35.

DUFRENE E. SAUGIER B., 1993 - Gas exchange of oil palm in relation to light, vapour pressure deficit, temperature and leaf age. - Funct. Ecol. 7: 97-104.

EGERT M., STING U., BRUUN L.D., BIANCA POMMERENKE B., BRUNE A., FRIEDRICH M.W., 2005 - Structure and topology of microbial communities in the major gut compartments of Melolontha melolontha larvae (Coleoptera: Scarabaeidae). - Appl. Environ. Microb. 71: 4556-4566.

FULCHER A.F., RANNEY T.G., BURTON J.D., 1998 - Role of foliar phenolics in host plant resistance of malus taxa to adult japanese beetles. - Hort. Sci. 33: 862-865.

GENTY P., DESMIER DE CHENON R., MORIN J., 1978 - The oil palm pest in Latin America. - Oléagineux 33: 326-420.

GIBLIN-DAVIS R.M., HOWARD F.W., 1989 - Vulnerability of stressed palms to attack by Rhynchophorus cruentatus (Coleoptera: Curculionidae) and insecticidal control of the pest. - J. Econ. Entomol. 82: 1185-1190.

HARTLEY M.J., 2002 - Rationale and methods for conserving biodiversity in plantation forests. - Forest Ecol. Manag. 155: 81-95.

HENSON I.E., 1990 - Photosynthesis and source-sink relationships in oil palm (Elaeis guineensis). T. - Malaysian Soc. Plant. Physiol. 1: 165-171.

HENSON I.E., 1991 - Limitations to gas exchange, growth and yield of young oil palm by soil water supply and atmospheric humidity. T. Malaysian Soc. Plant. Physiol. 2: 51-57.

KULKARNI N., CHANDRA K., WAGH P.N., JOSHI K.C., SINGH R.B., 2007 - Incidence and management of white grub, Schizonycha ruficollis on seedlings of teak (Tectona grandis Linn. f.). - Insect Sci. 14: 411-418.

MARIAU D., DESMIER DE CHENON R., SUDHARTO P.S., 1991 - Oil palm insect pests and their enemies in South East Asia. - Oléagineux 46: 400-476.

MARTINEZ L.C., HURTADO R.E., ARAQUE L., RINCON V., 2009. Advances of the regional campaign for the management information of defoliators in central zone. - Palmas 30: 11-21.

MICO E., MORON M.A., GALANTE E., 2003 - New larval descriptions and biology of some new world Anomalini beetles (Scarabaeidae: Rutelinae). - Ann. Entomol. Soc. Am. 96: 597-614.

NORDIN A.B.A., SIMEH M.A., AMIRUDDIN M.N., WENG C.K., SALAM B.A., 2004 - Economic feasibility of organic palm oil production in Malaysia. - Oil Palm Ind. Econ. J. 4: 29-38.

PARDO-LOCARNO L.C., MORÓN M.A., MONTOYA-LERMA J., 2006 Description of the immature stages of Leucothyreus femoratus Burmeister with notes on its biology and agricultural importance in Colombia. - Folia Entomol. Mex. 45: 179-193.

RAMIREZ-SALINAS C., CASTRO-RAMÍREZ A.E., 2000 - The complex white larvae (Coleoptera: Melolonthidae) in maize crop in El Madronal, municipality of Amatenango Del Valle, Chiapas, México. - Acta Zool. Mex. 79: 17-41.

RAMIREZ-SALINAS C., MORÓN M.A., CASTRO-RAMÍREZ A.E., 2004 Description of the immature stages of three Anomala, Ancognatha and Ligyrus (Coleoptera: Melolonthidae: Rutelinae and Dynastinae) with observations of its biology. - Acta Zool. Mex. 20: 67-82. 
RITCHER P.O., 1958 - Biology of Scarabaeidae. - Annu. Rev. Entomol. 3: 311-334.

RODRIGUES S.R., PUKER A., ABOT A.R., BARBOSA C.L., IDE S., COUTINHO G.V., 2008 - Occurrence and biological aspects of Anomala testaceipennis Blanchard (Coleoptera, Scarabaeidae). Rev. Bras. Entomol. 52: 68-71.

RODRIGUES S.R., PUKER A., TIAGO E.F., 2010 - Biological aspects of Leucothyreus dorsalis Blanchard (Coleoptera, Scarabaeidae, Rutelinae). - Rev. Bras. Entomol. 54: 431-435.

RODRIGUEZ-DEL-BOSQUE L.A., 1998 - A sixteen-year study on the bivoltinism of Anomala flavipennis (Coleoptera: Scarabaeidae) in Mexico. - Environ. Entomol. 27: 248-252.
SAS, 2002 - The SAS System for Windows, release 9.0. - SAS Institute, Cary, N.C.

SOLTANI R., CHAIEB I., HAMOUDA M.H.B., 2008 - The life cycle of the root borer, Oryctes agamemnon, under laboratory conditions. - J. Insect Sci. 8: 1-6.

TUKEY J.W., 1949 - Comparing individual means in the analysis of variance. - Biometrics 5, 99-114.

WOOD B.J., LIAU S.S., KNECHT J.C.X., 1974 - Trunk injection of systemic insecticides against the bagworm, Metisa plana (Lepidoptera: Psychidae) on oil palm. - Oléagineux 29: 499-505. 